\title{
Biomass composition of Arthrospira platensis during cultivation on industrial process water and harvesting
}

\author{
Ljubic, Anita; Safafar, Hamed; Holdt, Susan Løvstad; Jacobsen, Charlotte
}

Published in:

Journal of Applied Phycology

Link to article, DOI:

10.1007/s10811-017-1332-y

Publication date:

2018

Document Version

Peer reviewed version

Link back to DTU Orbit

Citation (APA):

Ljubic, A., Safafar, H., Holdt, S. L., \& Jacobsen, C. (2018). Biomass composition of Arthrospira platensis during cultivation on industrial process water and harvesting. Journal of Applied Phycology, 30(2), 943-954.

https://doi.org/10.1007/s10811-017-1332-y

\section{General rights}

Copyright and moral rights for the publications made accessible in the public portal are retained by the authors and/or other copyright owners and it is a condition of accessing publications that users recognise and abide by the legal requirements associated with these rights.

- Users may download and print one copy of any publication from the public portal for the purpose of private study or research.

- You may not further distribute the material or use it for any profit-making activity or commercial gain

- You may freely distribute the URL identifying the publication in the public portal 
1 Biomass composition of Arthrospira platensis during cultivation on industrial process water and harvesting

Anita Ljubic ${ }^{*}$, Hamed Safafar $^{2}$, Susan L. Holdt $^{1}$ and Charlotte Jacobsen ${ }^{1}$

${ }^{1}$ Technical University of Denmark, National Food Institute, Kemitorvet, Building 202, Kongens Lyngby 2800, Denmark; suho@food.dtu.dk (0000-0002-6888-782X); chja@ food.dtu.dk (0000-0003-3540-9669) "Author for correspondence: e-mail: aniljub@ food.dtu.dk (0000-0001-9370-8830), phone: +4581611094

Acknowledgments: The authors wish to acknowledge Inge Holmberg for her technical assistance. We would like to thank Kalundborg WWTP and Novozymes A/S for providing access to industrial process water.

Conflicts of Interest: The authors declare no conflict of interest.

Abstract

Microalgae have the ability to utilize nutrients from wastewater and use it for biomass production. The effluent from a biogas process was tested as a nutrient source for blue-green microalga Arthrospira platensis cultivation and compared with conventional synthetic medium. Cultivation was carried out in four different concentrations of industrial process water $(25 \%, 50 \%, 75 \%$ and $100 \%)$. The biomass was then harvested by microfiltration and centrifugation followed by freeze drying. Variations in biomass composition were studied, in order to investigate effects of industrial process water on A. platensis over 30 days of cultivation. Applied harvesting techniques were evaluated for their effect on physiochemical properties of the biomass. Arthrospira platensis was able to grow in all tested wastewater concentrations except $100 \%$, however, increase of wastewater concentration in medium resulted in a decreased growth rate. Partial substitution of synthetic Zarrouk medium with $25 \%$ of wastewater showed no adverse effect on chemical composition of the biomass including high protein content (45-58\% dry weight) and favourable fatty acids composition (42-45\% PUFAs of total fatty acids). Evaluation by optical microscopy showed that microfiltration caused cell rupture at the moderate level while centrifugation had more severe effect on $A$. platensis. Effect of centrifugal forces and shear stress on A. platensis cells was confirmed by 
detecting lower lipid content in samples after applying both microfiltration and centrifugation due to cell content leakage.

Keywords: Spirulina, wastewater, biomass composition, cross-flow microfiltration, centrifugation, cell rupture.

\section{INTRODUCTION}

Microalgae are a group of microscopic organisms with a broad phylogenetic diversity. They are a potential sustainable source of feedstock that can be harnessed for commercial use, due to their high photosynthetic activity, short growth cycle and low land area requirements compared to terrestrial plants (Mata et al. 2010). During the last 30 years, the microalgal industry has grown significantly. The first large-scale cultivation facilities were established as the potential solution for the food and feed shortage. Nowadays, different species of microalgae, mainly from the genus Chlorella, Dunaliella and Arthrospira, are used for mass cultivation with a wide range of applications such as bioenergy production, food and feed supplements and pharmaceutical products (Priyadarshani and Rath 2012; Milledge 2011).

Arthrospira platensis, traditionally known as Spirulina, is a photosynthetic, prokaryotic, blue green microalgae. Characteristic morphological features of A. platensis are the spiral shape of multicellular cylindrical filaments in an open helix with the length from $0.3-1.0 \mathrm{~mm}$. It is considered to be sensitive towards external stress, due to the relatively large size and fragile cellulose-free cell wall, and therefore external stress is found to facilitate extraction of essential compounds. Typical chemical composition of A. platensis is $55-70 \%$ proteins, $15-25 \%$ carbohydrates and 4-7\% lipids (Ali and Saleh 2012). It serves as a rich source of essential nutrients such as vitamins, minerals, proteins including all the essential amino acids, pigments and polyunsaturated fatty acids (PUFAs). Due to the high content of biological active compounds, it has found applications in human and animal nutrition, cosmetics, high-value molecules production for pharmaceuticals etc. (Priyadarshani and Rath 2012).

Despite the large potential and wide range of applications, industrial production of microalgal biomass often meets economical challenges. However, several approaches have been considered for production process optimization and thereby a reduction of production costs (El-Sheekh et al. 2016; Barros et al. 2015). Using wastewater as complete or partial substitution of synthetic growth 
medium can reduce production costs and fresh water requirement (Abdel-Raouf et al. 2015). Bioremediation by microalgae is particularly effective due to their ability to assimilate nutrients and to convert light energy into valuable biomass. Thus, applying wastewater as cultivation medium presents environmentally beneficial sources of carbon, nitrogen and phosphorous for microalgae growth (El-Sheekh et al. 2016). Efficient bioremediation of A. platensis was reported previously in several studies (Markou et al. 2016; Mezzomo et al. 2010; Phang et al. 2000). In the present study industrial process water (ICW) was acquired by methanogenic conversion of organic compounds to methane, carbon dioxide and an effluent with relatively high ammonia content. The anaerobic digestion process was carried out in an anaerobic sludge tower reactor with internal circulation (ICT), therefore, the effluent is called IC water (ICW). The growth performance of several microalgae species was previously tested on ICW where some of the tested species showed ability to grow even on $100 \%$ ICW (Safafar 2017). In general, microalgae use nitrogen in amino acid, protein and pigment syntheses and it is utilized in the form of nitrate $\left(\mathrm{NO}^{-3}\right)$, nitrite $\left(\mathrm{NO}^{-2}\right)$ or ammonia $\left(\mathrm{NH}_{3}\right)$. However, as long as $\mathrm{NH}_{3}$ is available most of the microalgal cells will not utilize other nitrogen sources because assimilation of any other nitrogen form requires energy consumption for reduction (Chaiklahan et al. 2010).

Another optimizing approach relates to downstream processes due to their high share of the total production costs. Harvesting presents a major challenge due to the small size of microalgae cells and low density of the cultures. An efficient optimized harvesting process should be suitable for a variety of microalgae strains resulting in high biomass concentrations while requiring low operational costs for energy and maintenance (Barros et al. 2015). Among many harvesting techniques, centrifugation is the most energy-intensive harvesting method. Regardless of that, due to its high separation efficiency and ability to harvest a large majority of microalgae, it is the most commonly used harvesting method in lab-scale and large-scale microalgal plant systems (Dassey and Theegala 2013). In order to decrease energy demand, microalgae can be pre-concentrated before centrifugation. Membrane filtration presents an optimal pre-treatment process, where biomass can be pre-concentrated 5-10 times (Bilad et al. 2014). It represents closed harvesting system, which is commonly needed for production of high valued products (e.g. omega-3-fatty acids, pigments). However, it has previously been reported that exposure of microalgal cells to high gravitational forces during centrifugation and providing sufficient shear at the membrane surface during filtration can lead to structural cell damage (Safafar 2017; Xu et al. 2015; Bilad et al. 2014). Whether this happens will to a large degree depend on the applied force level and the specific 
features of the microalgal strain. Unwanted cell disruption liberates the cell content, which can greatly reduce the shelf life and nutrition value of the microalgal biomass.

The aim of this study was to investigate the effects of different concentrations of ICW during cultivation on biomass production and nutritional composition of A. platensis. This study evaluated the optimal ICW concentration for obtaining maximum biomass production and favourable biomass composition (proteins, lipids, fatty acids, pigments and amino acids). Furthermore, the applied twostep harvesting process (cross-flow microfiltration and centrifugation) was tested for its effect on the changes in the biomass as a result of external stress exposure with an aim of investigating potential for developing large scale harvest process after cultivation in photo bioreactors.

\section{MATERIALS AND METHODS}

\subsection{Microalgal cultivation and growth measurements}

Arthrospira platensis (SAG 85.79) was obtained from SAG (Sammlung von Algenkulturen der Universität Göttingen) culture collection of algae in Germany. The inoculum was prepared in synthetic Zarrouk medium (ZM; Zarrouk 1966) with the following composition: $16.8 \mathrm{~g} \mathrm{~L}^{-1}$ $\mathrm{NaHCO}_{3}, 2.5 \mathrm{~g} \mathrm{~L}^{-1} \mathrm{NaNO}_{3}, 0.5 \mathrm{~g} \mathrm{~L}^{-1} \mathrm{KH}_{2} \mathrm{PO}_{4}, 1.0 \mathrm{~g} \mathrm{~L}^{-1} \mathrm{~K}_{2} \mathrm{SO}_{4}, 1.0 \mathrm{~g} \mathrm{~L}^{-1} \mathrm{NaCl}, 40 \mathrm{mg} \mathrm{L} \mathrm{CaCl}_{2}, 80$ $\mathrm{mg} \mathrm{L}^{-1} \mathrm{Na}_{2}$ EDTA, $200 \mathrm{mg} \mathrm{L}^{-1} \mathrm{MgSO}_{4} \cdot 7 \mathrm{H}_{2} \mathrm{O}, 10 \mathrm{~g} \mathrm{~L}^{-1} \mathrm{FeSO}_{4} \cdot 7 \mathrm{H}_{2} \mathrm{O}$ and $1.0 \mathrm{~mL}$ of trace elements stock solutions: $2.86 \mathrm{~g} \mathrm{~L}^{-1} \mathrm{H}_{3} \mathrm{BO}_{3}, 20 \mathrm{mg} \mathrm{L}^{-1}\left(\mathrm{NH}_{4}\right)_{6} \mathrm{Mo}_{7} \mathrm{O}_{24}, 1.8 \mathrm{~g} \mathrm{~L}^{-1} \mathrm{MnCl}_{2} \cdot 4 \mathrm{H}_{2} \mathrm{O}, 80 \mathrm{mg} \mathrm{L}^{-1}$ $\mathrm{CuSO}_{4}$ and $220 \mathrm{mg} \mathrm{L}^{-1} \mathrm{ZnSO}_{4} \cdot 7 \mathrm{H}_{2} \mathrm{O}$. Industrial process water (ICW) used for the experiments was obtained from Novozyme's plant (Kalundborg, Denmark) and it was filtered by cross-flow microfiltration $(0.2 \mu \mathrm{m}$ pore size $)$ prior use. Chemical composition of ICW is presented in Table 1 .

The cultivation experiments were carried out in two sets using 1 and 5 L GS Schott bottles. First set of experiments (preliminary experiments) included 12 days cultivation of A. platensis in four different concentrations of ICW $(25 \%, 50 \%, 75 \%$ and $100 \%$ (all concentrations were prepared in ZM)) and 100\% Zarrouk medium. Working volume was $1 \mathrm{~L}$ including $100 \mathrm{ml}$ of inoculum.

The second set of experiments was designed based on the growth curves acquired from the first set of experiments. Two best growing cultures were recultivated in $5 \mathrm{~L}$ bottles in order to collect samples during cultivation period. Therefore, the second set of experiments included cultivation in $25 \%$ ICW and $100 \%$ ZM in duplicates over 31 days with a working volume of $5 \mathrm{~L}$. Both ICW and $\mathrm{ZM}$ were autoclaved before use at $120{ }^{\circ} \mathrm{C}$ for $45 \mathrm{~min}$. The cultures were aerated with a mixture of carbon dioxide (5\%) and sterile air. Cultivation temperature range was $25 \pm 1{ }^{\circ} \mathrm{C}$ and $\mathrm{pH}$ range 
9.5 \pm 5 . $\mathrm{pH}$ monitoring was performed by Milwaukee MC-122-pH controller (Milwaukee Electronics, Szeged, Hungary) equipped with a solenoid valve to control $\mathrm{CO}_{2}$ addition. Provided light intensity was $100 \mu \mathrm{mol}$ photons $\mathrm{m}^{2} \mathrm{~s}^{-1}$ (measured on the outer side of the bottle) under fluorescent lamp illumination (Green-line A/S, Maribo, Denmark) during 14/10 hours of light/dark cycle.

Growth was monitored daily by taking $5 \mathrm{~mL}$ culture sample and measuring optical density at 670 nm. Dry matter was determined on a daily basis by taking liquid samples, weighing and drying in oven at $100{ }^{\circ} \mathrm{C}$ until dryness, kept in desiccator, cooled down to room temperature and weighted. The specific growth rate was calculated using the following formulae (Guillard and Ryther 1962):

$$
\mu=\frac{\ln \frac{x_{1}}{x_{0}}}{t_{1}-t_{0}}
$$

where $\mathrm{x}_{1}$ and $\mathrm{x}_{0}$ were biomass concentrations $\left(\mathrm{g} \mathrm{L}^{-1}\right)$ at $\mathrm{t}_{1}$ and $\mathrm{t}_{0}$ cultivation days, respectively.

\subsection{Analytical methods}

For chemical analysis $0.4 \mathrm{~L}$ of culture was sampled. In order to achieve biomass separation, samples were centrifuged at $11000 \times \mathrm{g}$ and the biomass was washed by deionized water. The resulting biomass was freeze dried and stored at $-20{ }^{\circ} \mathrm{C}$ until analysis.

The protein concentration in the microalgal samples (approximately $1 \mathrm{~g}$ of dried microalgal biomass) was estimated using the Dumas method for the quantitative determination of nitrogen in different matrices (Elementar, Mt. Laurel, NJ, USA). The following steps were automated including sample combustion in a chamber at a high temperature $\left(900{ }^{\circ} \mathrm{C}\right)$ in the presence of oxygen. Conversion of the estimated total nitrogen content to the crude protein was done using conversion factor 6.35 for A.platensis reported by Safi et al. (2013). Protein concentration is reported as \% of dry biomass.

The amino acid composition was analyzed using Phenomenex EZ:faast ${ }^{\mathrm{TM}}$ amino acid analysis kit (Phenomenex Inc. CA, USA). Approximately $30 \mathrm{mg}$ of dry microalgal biomass was weighted in microwave glass vials. Samples were hydrolyzed in $6 \mathrm{M} \mathrm{HCl}$ in a microwave oven (Microwave 3000 SOLV, Anton Paar, Ashland, VA, USA) for 60 minutes at $110^{\circ} \mathrm{C}$. Amino acid derivatization was done by following clean-up steps in order to remove matrix interference. Liquid chromatography with Agilent 1100 series LC/MSD Trap mass spectrometry (Agilent technologies, Santa Clara, CA, USA) was used for amino acid composition determination. Applied column was EZ:fast ${ }^{\text {TM }}$ LC-MS column $(250 \times 3.0 \mathrm{~mm}$, Phenomenex, Torrance, CA, USA $)$. Amino acids are reported as $\mu \mathrm{g} / \mathrm{g}$ of dry biomass. 
Lipids were extracted from approximately $1 \mathrm{~g}$ of dried microalgal biomass by subsequent addition of methanol, chloroform and water while stirring as described by Bligh \& Dyer (1959), but with a reduced amount of solvent. Samples were centrifuged at $1400 \times g$ for $10 \mathrm{~min}$, in order to separate methanol/water phase from chloroform/oil phase. Bligh \& Dyer extracts were used for analyses of oil content, fatty acids and tocopherols. For determining total lipid content around $15 \mathrm{~g}$ of extract was weighted in beakers and left overnight in a fume hood in order to evaporate chloroform. Lipid content was calculated using the equation below (2).

$$
\% \text { lipid }=\frac{g(\text { lipid }) * 41 g * 100}{(g(\text { extract })-g(\text { lipid }) * g(\text { sample })}
$$

Fatty acid profile was determined according to a slightly modified FAME method based on the American Oil Chemist's Society (AOCS) official method Ce 1i-07 (Firestone 2009). Approximately $5 \mathrm{~g}$ of Bligh \& Dyer extract was weighted in methylation glass tube. Extracts were evaporated under the stream of nitrogen until they were completely dry. A mixture containing $100 \mu \mathrm{L}$ of internal standard solution, $200 \mu \mathrm{L}$ of heptane with BHT and $100 \mu \mathrm{L}$ of toluene was added. Samples were methylated in a microwave oven (Microwave 3000 SOLV, Anton Paar, Ashland, VA, USA) for $10 \mathrm{~min}$. at $100{ }^{\circ} \mathrm{C}$ at 500 watts. $0.7 \mathrm{~mL}$ of heptane with BHT and $1 \mathrm{~mL}$ of saturated salt water $(\mathrm{NaCl})$ were added. The separated upper phase (heptane) was transferred into vials and analyzed by gas chromatography (HP-5890 A, Agilent Technologies, Santa Clara, CA, USA). Fatty acid methyl esters were separated by the GC column Agilent DB wax 127-7012 (10 $\mu \mathrm{m}$ x $100 \mu \mathrm{m}$ x $0.1 \mu \mathrm{m}$; Agilent technologies, Santa Clara, CA, USA). Standard mix of fatty acids methyl esters (Sigma, St. Louis, MO, USA) was used for identification of individual fatty acid. Fatty acids were quantified as in area $\%$ of total fatty acids.

Pigment analysis was done by the method described by Safafar et al. (2015). Extraction was carried out on approximately $0.05 \mathrm{~g}$ of dried algal biomass by methanol containing BHT in a sonication bath (Branson Ultrsonics, Danbury, CA, USA) for $15 \mathrm{~min}$ at $5 \pm 2{ }^{\circ} \mathrm{C}$. Pigments analysis was performed by HPLC using Agilent 1100 Liquid Chromatograph with DAD. Separation was carried out on a Zorbax Eclipse C8 column $150 \mathrm{~mm}$ x $46 \mathrm{~mm}$ x $3.5 \mu \mathrm{m}$ (Phenomenex Inc. CA, USA). The mobile phase was a mixture of $70 \%$ methanol $+30 \%$ of $0.028 \mathrm{M}$ tertiary butyl ammonium acetate in water and methanol at a flow rate of $1.1 \mathrm{~mL} \mathrm{~min}^{-1}$ with total acquisition time of $40 \mathrm{~min}$. Identification of peaks was performed using DHI pigment standard mix (DHI LAB Products, Horsholm, Denmark). Detection of chlorophylls and carotenoids was done at $660 \mathrm{~nm}$ and $440 \mathrm{~nm}$, 
respectively, and for internal standard (BHT) at $280 \mathrm{~nm}$. Pigments are reported as $\mu \mathrm{g} \mathrm{g}^{-1}$ of dry biomass.

\subsection{Harvest - microfiltration and centrifugation}

Harvest of microalgal biomass was carried out after 30 days of cultivation (cultivation conditions described in section 2.1), in a batch mode by tangential flow filtration using a silicon carbide membrane with pore size $3 \mu \mathrm{m}(\varnothing 25 \times 305 \mathrm{~mm}, \varnothing 3 \mathrm{~mm}$ channel; Liqtech A/S, Denamrk). The laboratory scale filtration unit (Liqtech A/S, Denmark) had a capacity of 20-50 L h${ }^{-1}$, and $5 \mathrm{~L}$ of algal biomass was used during the filtration process at a constant pressure of $1.0 \pm 0.2$ bar and a temperature of $20 \pm 3{ }^{\circ} \mathrm{C}$. Harvested microalgal biomass was recycled by the pump (WatsonMarlow 604 U/R, Falmouth, Cornwall, UK) back to the feed tank, so that the concentration of the feed increased, with processing time. A schematic drawing of the used batch mode microfiltration process is shown in Fig. 1. Calculation of flux, filtration rate and concentration ratio was done by the following formulae (EPA 2005):

$$
J=\frac{\square p}{A_{m}}
$$

$\mathrm{J}=$ flux $\left(\mathrm{L} \mathrm{h}^{-1} \mathrm{~m}^{-2}\right) ; \mathrm{Q}_{\mathrm{p}}=$ filtrate flow rate through membrane $\left(\mathrm{L} \mathrm{h}^{-1}\right) ; \mathrm{A}_{\mathrm{m}}=$ surface area of membrane $\left(\mathrm{m}^{2}\right)$

$$
J_{\text {avg }}=J_{0}-0.33\left(J_{0}-J_{f}\right)
$$

$\mathrm{J}_{\mathrm{avg}}=$ average flux rate; $\mathrm{J}_{0}=$ initial flux; $\mathrm{J}_{\mathrm{f}}=$ final flux

$$
C F=\frac{C_{f}}{C_{0}}
$$

$\mathrm{CF}=$ concentration ratio; $\mathrm{C}_{\mathrm{f}}=$ final concentration of a given solute $\left(\mathrm{g} \mathrm{L}^{-1}\right) ; \mathrm{C}_{0}=$ initial concentration of the solute $\left(\mathrm{g} \mathrm{L}^{-1}\right)$.

A bench scale centrifuge (refrigerated centrifuge, IEC Centra-GP8R, Buckinghamshire, England) was used for the biomass up-concentration after applying microfiltration. Complete separation was accomplished at $11000 \mathrm{x} g$ for $10 \mathrm{~min}$. The supernatant was discarded and microalgal biomass was freeze-dried. Protein, lipid and pigment content, as well as the fatty acid composition were determined in order to evaluate changes in the biomass composition (same procedures as describes above). In addition, samples were evaluated by optical microscopy. 


\subsection{Statistical analysis}

Cultivation experiments in $5 \mathrm{~L}$ bottles were carried out in 2 biological replicates (second set of experiments). All compositional analyses were performed on the samples from $5 \mathrm{~L}$ and repeated two times. The results are given as the mean ( \pm standard deviation). Analysis of variance (two-way ANOVA) was used to evaluate the effect of time and growth media on chemical composition of biomass. Data have met the assumption of normality and homogeneity of variance. Tukey's post hoc test was used to detect significant differences between groups where $p$ values $<0.05$ were considered significant. The Statistica v. 13.2 software (Dell Inc.,Tulsa, OK, USA) was used for all statistical analyses.

\section{RESULTS}

\subsection{Growth characteristics of $A$. platensis}

Arthrospira platensis biomass concentration was continuously increasing in three tested ICW concentrations $(25 \%, 50 \%, 75 \%)$ over the 12 days of cultivation (Fig. 2). However, it showed no ability for growing on $100 \%$ ICW. Biomass increment curves indicate that the increase in concentration of ICW resulted in lower biomass accumulation. The highest biomass increment was detected in $100 \%$ ZM. Standard curve of concordance between optical density and dry matter showed strong correlation $\left(\mathrm{R}^{2}=0.99\right.$; not shown) of $A$. platensis cultivated in $25 \%$ ICW and $100 \%$ ZM in experiment 2 (Fig. 3). Specific growth rate $(\mu)$ of A. platensis was $0.098 \pm 0.002$ day $^{-1}$ and $0.089 \pm 0.005$ day $^{-1}$ cultivated in $100 \% \mathrm{ZM}$ and $25 \% \mathrm{ICW}$, respectively. No significant difference ( $\mathrm{p}>0.05$ ), in biomass accumulation was observed between the cultures in $100 \% \mathrm{ZM}$ and $25 \%$ ICW during first 20 days of cultivation, after which A. platensis cultivated in $100 \% \mathrm{ZM}$ grew significantly faster.

\subsection{Biomass composition}

Total protein and lipid concentration of A. platensis were not significantly affected $(\mathrm{p}>0.05)$ by growth medium or cultivation time (Fig. 4 and 5). Protein concentration varied from $44-52 \%$ and $50-58 \%$ of dry biomass for A. platensis cultivated in 100\% ZM and 25\% ICW, respectively. Hultberg et al. (2016) tested protein content of A. platensis cultivated in Zarrouk medium (54-66\%) and effluent-based medium (60-66\%) where they reported no significant differences between the cultures grown in different medium, which corresponds to our study. Lipid concentration of $A$. 
platensis varied from 4-6\% of dry biomass for both cultures and similar values were reported in the few previous studies with A. platensis (Baunillo et al. 2012; Colla et al. 2007). The amino acid composition of A. platensis grown on different growth media is shown in Fig. 6a,b. Principal amino acids included leucine, valine, glutamine and alanine, which is in agreement with the study reported by Hultberg et al. (2016). The amino acid compositions were similar in A. platensis cultivated in $100 \% \mathrm{ZM}$ and $25 \%$ ICW with no significant differences ( $\mathrm{p}>0.05)$. Tryptophan was not detected in any of the cultures and it assumed that it was due to the fact that it is destroyed during the hydrolysis. The current study confirms the presence of all essential amino acids with particularly high contents of valine, 13-17\%, and leucine, 11-17\% of total amino acids. Significantly higher contents ( $\mathrm{p}$ 0.05), of essential amino acids, compared to non-essential amino acids, were present in algal biomass, however no significant difference between the proportions of essential and nonessential amino acids, when comparing the two growth media (Table 3).

Arthrospira platensis is rich in a $\gamma$-linolenic acid (18:3 (n-6)) from omega-6 family. Other major fatty acids in A. platensis are palmitic acid (16:0) and essential linoleic acid (18:2 (n-6)), and the latter a precursor for synthesis of other polyunsaturated fatty acids. In the current study, these fatty acids constitute $78-83 \%$ of total fatty acids. There was no significant differences ( $p>0.05)$, in fatty acid composition between different treatments (Table 4a,b), which agrees with previous findings on A. platensis cultivated in ZM and anaerobic digestate effluent (Hultberg et al. 2016).

The pigment composition of A. platensis includes phycobiliproteins, chlorophylls and carotenoids. In this study chlorophylls and carotenoids were analyzed (Fig. 7a,b), which are rarely reported for Arthrospira sp. in contrast to the most abundant phycobiliproteins. Both treatments were showing similar pigment composition pattern with no significant differences $(\mathrm{p}>0.05)$. Slightly higher, although not significantly, concentration of pigments was observed in A. platensis cultivated in $100 \%$ ZM. Concentrations of pigments in A. platensis increased over the 30 days of cultivation, which positively correlate with the biomass production. The highest estimated concentration of chlorophyll a was $4.099 \pm 67 \mu \mathrm{g} \mathrm{g}^{-1}$, followed by carotenoids: zeaxanthin $\left(1.465 \pm 531 \mu \mathrm{g} \mathrm{g}^{-1}\right), \beta$ carotene $\left(1.745 \pm 132 \mu \mathrm{g} \mathrm{g}^{-1}\right)$ and astaxanthin $\left(433 \pm 59 \mu \mathrm{g} \mathrm{g}^{-1}\right)$.

\subsection{Harvest - microfiltration and centrifugation}

Microfiltration showed to be an efficient harvesting method with no membrane fouling during the biomass separation. Arthrospira platensis cell size is relatively big, which favours separation 
282 efficiency. Average flux $\left(\mathrm{J}_{\text {avg }}\right)$ was $405.3 \mathrm{~L} \mathrm{~m}^{-2} \mathrm{~h}^{-1}$ with a concentration ratio $(\mathrm{CF})$ of 5.16, which is 283 above average compared to other microalgal species (Monodopsis subterranea, Nannochloropsis 284 salina, Chlorella vulgaris) harvested by cross-flow microfiltration under the same conditions 285 (Safafar 2017).

286 Exposure of $A$. platensis to transmembrane pressure during microfiltration, and high gravitational 287 and shear forces during centrifugation may cause structural cell damage (Xu et al. 2015; Bilad et al. 288 2014). The fresh culture of A. platensis (Picture 1a) showed no cell damage, while after applying 289 harvesting processes cell rupture was detected (Picture 1b,c). Biomass, analyzed after 290 microfiltration step, showed moderate cell damage, while applying microfiltration followed by 291 centrifugation, resulted in severe cell damage. Microscopy showed (circled points) indicators of 292 possible cell rupture such as presence of exopolysaccharides (EPS) and cellular fragments. EPS are 293 polymers composed of sugar residues that are secreted by microalgae into the surrounding 294 environment under stress conditions such as external pressure during harvest.

295 Protein, lipid and pigment composition were determined in order to test effects of applied 296 harvesting techniques on changes in A. platensis biomass. Significantly lower $(\mathrm{p}<0.05)$, protein, 297 lipid and chlorophyll content were detected in samples experiencing both microfiltration and 298 centrifugation compared to only microfiltration (Table 5), which indicates more severe cell rupture 299 and leakage of the cell content.

300

\section{DISCUSSION}

\subsection{Growth and chemical composition}

303

304 305 306 307 308 309 310 311 312

Arthrospira platensis grows optimally under alkaline conditions, which means it requires use of inorganic carbon from bicarbonate. Uptake of this inorganic carbon is possible due to the welldeveloped carbon concentrating mechanism (CCM) in A. platensis (Klanchui et al., 2017). ZM contains $16.8 \mathrm{~g} \mathrm{~L}^{-1}$ of sodium bicarbonate whereas ICW has no bicarbonate present. This could be the reason for no growth detected in $100 \%$ ICW (Fig. 2). Furthermore, sodium and chloride ions affect the osmotic pressure of the solution. Therefore osmolarity factor may contribute significantly to the growth of A. platensis. Sodium concentration in ICW was significantly lower as compared to ZM, which indicates that diluting ZM by ICW will result in salinity reduction. Lowering salinity level may contribute to growth inhibition. In addition, ICW contains cyanide, which has toxic effect on microalge, which could be another possible reason for growth inhibiton. 
Shorter adaptation period (lag phase) for A. platensis cultivated in lower levels of ICW and in ZM can be attributed also to a relatively low initial pH 8.1 of ICW compared to 9.3 in ZM (Fig. 2). Kim et al. (2007) reported the highest biomass accumulation of A. platensis at $\mathrm{pH} 9.5$, which was later confirmed by Soundarapandian and Vasanthi (2008). The proposed explanation was that optimal activity of all the enzymes needed for photosynthesis and respiration is lower at below-optimal $\mathrm{pH}$. Leema et al. (2010) reported $0.23 \mathrm{day}^{-1}$ for A. platensis grown under similar conditions as in the current study. Observed deviations in these values and ones determined in this study are most likely result of the light limitation during cultivation. Growth rate of A. platensis strongly depends on the photosynthesis capacity, which depends on the light availability. In addition, high cell densities cause mutual shading and increase in turbidity of the culture, which will cause lower photosynthetic activity (Wondraczek et al. 2013). In a study by Leema et al. (2010), cultivation was carried out in $500 \mathrm{~mL}$ bottles and higher $\mu$ was reported when comparing to $5 \mathrm{~L}$ glass bottle used in the current study. This can be confirmed by comparing biomass increment curves in Fig. 2 and 3, where OD 670 is higher for A. platensis cultivated in $1 \mathrm{~L}$ bottle (Fig. 2) compared to A. platensis cultivated in $5 \mathrm{~L}$ bottle (Fig. 3) for the same time period. Light is a major factor influencing also pigment synthesis in microalgae. When microalgae are cultivated under a constant light intensity, the light intensity per cell will decrease due to the increase in cell density. Therefore, mutual shading will lead to the increase in pigment concentration as a result of competition for light harvesting (Myers and Kratz 1955), which was confirmed by this study. Moreover, the increase of the total chlorophyll content during cultivation period indicates that the growth medium was nitrogen sufficient, otherwise chlorophyll content would decrease as a result of nitrogen limitation for the synthesis (Cohen 1997). In general, the chemical composition of $\mathrm{ZM}$ had higher concentration of inorganic carbon $\left(\mathrm{NaHCO}_{3}\right)$ available for A. platensis growth, which is most likely the main reason for increased biomass accumulation after day 20 (Fig. 3). Another important difference between ICW and ZM is nitrogen source, ammonia $\left(\mathrm{NH}_{3}\right)$ and nitrate $\left(\mathrm{NO}^{-3}\right)$, respectively. Ammonia concentration is known to be a critical factor for A. platensis biomass accumulation and even though it presents the most preferable chemical form of nitrogen available to microalgae, high ammonia concentration has inhibitory effect on the growth of A. platensis. Ogbonna et al. (2000) reported complete inhibition of A. platensis by $400 \mathrm{mg} \mathrm{L}^{-1}$ of ammonia in the growth medium. Markou et al. (2014) suggested that low biomass densities are more susceptible to ammonia inhibition compared to high densities. In contrast, higher biomass densities assimilate ammonia rapidly as a response to inhibition. In our study concentration of ammonia in $100 \% \mathrm{ICW}$ was $150 \mathrm{mg} \mathrm{L}^{-1}$ and initial biomass density was low, 
which resulted in complete growth inhibition. However, A. platensis cultivated in $75 \%$ ICW, where ammonia concentration was $112.5 \mathrm{mg} \mathrm{L}^{-1}$ showed biomass increment after 6 days of adaptation. In contrast, $100 \% \mathrm{ZM}$ contained nitrate as nitrogen source with no ammonia and gave higher biomass yields compared to ZM diluted with ICW. Depleted amount of nitrogen present in the growth medium was estimated (data not shown) based on the chemical composition of A. platensis biomass. The data suggest that there was no nitrogen starvation in any of the two cultures.

Protein synthesis is greatly affected by nitrogen level in the growth medium, which was confirmed by Sassano et al. (2010) who reported significant changes in protein content of A. platensis affected by nitrogen availability in the growth medium. Sufficient levels of nitrogen, means that carbon provided through the photosynthesis, will be used in protein synthesis $(\mathrm{Hu}, 2013)$. During starvation phase, when nitrogen limitation is present, lipids or carbohydrate will start accumulating. It is known that microalgae lipid accumulation can be enhanced by nitrogen limitation. However, it was also suggested that higher cultivation temperature $\left(30-35{ }^{\circ} \mathrm{C}\right)$ may increase lipid accumulation in A. platensis (Markou et al. 2016; Colla et al. 2007). The fact, that there was no significant decrease in protein concentration or increase in lipid concentration over time (Fig. 4 and 5), suggest that $A$. platensis had sufficient nitrogen level in both experiments, and did not reach the stationary phase during 31 days of cultivation. Furthermore, it is expected that decrease in protein content would be observed first in culture grown on medium with $25 \% \mathrm{ICW}$, due to the lower nitrogen content compared to $100 \% \mathrm{ZM}$. In addition, sodium nitrate $\left(\mathrm{NaNO}_{3}\right)$, which is the nitrogen form available in $\mathrm{ZM}$, was found to be the most preferable nitrogen form for A. platensis utilization (Costa et al. 2001). Arthrospira platensis is a well-known rich source of high quality protein, which refers to the quantity of essential amino acids and high digestibility for animal and human organisms (Becker, 2007). It can compete, due to its favourable amino acid composition and concentration, with other plant proteins such as soybean, where the content of essential amino acids is lower per unit of mass (Becker, 2007).

Arthrospira platensis is a known commercial producer of $\gamma$-linolenic acid (18:3 (n-6)), which is a highly valuable fatty acid from the omega- 6 family. The content of this fatty acid can reach up to $30 \%$ of total fatty acids (Muhling et al. 2005). Saturated fatty acids start to accumulate, when the nitrogen concentration in the growth medium is limited ( $\mathrm{Hu}$ et al. 2008). This finding confirms again that there was no nutrient limitation during the cultivation period for A. platensis in this study. However, there was a significant increase in the proportion of linoleic acid, and a decrease in $\gamma$ linolenic acid during the cultivation period. This trend indicates that there is a correlation between 
the syntheses of these fatty acids. Thus, a possible transformation of tri-unsaturated fatty acid into di-unsaturated is suggested. Similar transformations have already been proven for some fatty acids in the process called retro-conversion, such as docosahexaenoic acid (22:6) transformed to eicosapentaenoic acid (20:5) and docosapentaenoic acid (22:5) transformed to arachidonic acid (20:4) in mammals. Also, it is suggested that microscopic organisms of phylum Rotifers and organisms of genus Artemia have the same ability (Barclay and Zeller 1996). This has not previously been reported in algal organism. However, it cannot be ruled out that retro-conversion is a process that can occur in fatty acids metabolism of other organisms than suggested by literature. In general, Artrospira sp. has higher content of $\gamma$-linolenic acid compared to the content of linoleic acid (Muhling et al. 2005). However, Muhling et al. (2005) reported the fatty acid composition of 35 Arthrospira strains and observed different proportions of linoleic acid and $\gamma$-linolenic acid in $A$. platensis (strain SAG 85.79) compared to other A. platensis strains, where strain SAG 85.79 had considerably higher content of linoleic acid. Therefore, fatty acids composition reported in our study is in agreement with the study by Muhling et al. (2005).

\subsection{Harvesting}

In general, during harvesting the membrane is gradually being fouled during microfiltration, due to clogging of pores by small particles. Source of fouling can be the cell content released, due to the cell wall damage, or extracellular polymeric substances (exopolysaccharides) extracted by the cell under stress conditions (Rossi et al. 2008). Therefore, flux is being reduced over time as a result of gradual fouling (Fig. 8). If the cell rupture was severe during microfiltration, complete membrane fouling would occur fast and separation efficiency (average flux and concentration ratio) would decrease. According to $\mathrm{Xu}$ et al. (2015) high centrifugal forces can cause microalgae cell rupture, with a loss up to $40 \%$ of total lipid content. The level of disruption depends on the toughness and shape of the microalgae cell, as well as the hydrodynamic forces applied to the microalgae (Xu et al. 2015). According to Safafar (2017) larger average cell size will result in higher degree of the leakage, which is in agreement with the results of this study.

Chlorophyll content was higher before centrifugation and decreased after (Table 5). By damaging cell wall, content of the cell will lack the protection layer, which can result in pigment degradation (Hosikian et al. 2010). However, the content of $\beta$-carotene significantly increased after centrifugation. Carotenoids accumulate in the chloroplasts and recover in the cell at high centrifugation forces. Therefore, cell rupture can have both positive and negative consequences, 
depending on the final product. If the aim is to achieve a high extractability of different compounds from the cell, already broken cell walls will favour the extraction process.

\section{CONCLUSION}

Arthrospira platensis was able to grow on different dilutions of ICW, which offers potential lowcost source of nutrients for microalgal growth. Partial substitution of synthetic medium with wastewater can potentially reduce microalgal production costs and reduce fresh water requirements. Growth was not detected in $100 \%$ ICW due to the non-optimal environment for growth of $A$. platensis. Optimal concentration of ICW for obtaining high growth rate with no adverse effect on the biomass composition was shown to be $25 \%$ dilution in synthetic medium. This study suggests $A$. platensis as a potential species for wastewater treatment. Further research is needed in order to investigate the efficiency of the nutrient removal from industrial process water, as well as testing of possible toxic compound concentrating in the biomass. Furthermore, different environmental stress factors could be tested in combination with ICW, in order to increase production of valuable compounds such as protein, PUFAs and carotenoids.

Harvesting methods should be adjusted for specific microalgal species due to their wide diversity. A suitable process needs to be applied, in order to preserve quality of the end product. Microfiltration was demonstrated to be an efficient method for biomass separation with moderate cell rupture, as a result of the filtration shear. However, economically it still cannot compete with standard passive screen filtration commonly used for filamentous and large cell size specie. Also, microfiltration by itself may not be sufficient for harvesting, in case it is necessary to further up-concentrate the microalgal biomass before drying, which then requires additional up-concentrating steps. Centrifugation was shown not to be a suitable harvesting (or up-concentration) method for A. platensis due to severe cell damage, followed by cell content leakage. Effects of centrifugal force on A. platensis were confirmed by changes in biomass composition including lower protein, lipid and chlorophyll content after centrifugation. 


\section{References}

Abdel-Raouf N, Al-Homaidan AA, Ibraheem IBM (2012) Microalgae and wastewater treatment. Saudi J Biol Sci 19:257-275.

Ali SK, Saleh AM (2012) Spirulina: an overview. Int J Pharm Pharm Sci 4(3), 9-15.

Barclay W, Zeller S (1996) Nutritional enhancement of n-3 and n-6 fatty acids in Rotifers and Artemia Nauplii by feeding spray-dried Schizochytrium sp. J World Aquacult Soc 27: 314-322.

Barros AI, Gonçalves AL, Simões M, Pires JCM (2015) Harvesting techniques applied to microalgae: A review. Renew Sust Energ Rev 41:1489-1500.

Baunillo KE, Tan RS, Barros HR, Luque R (2012) Investigations in microalgal oil production from Arthrospira platensis: towards more sustainable biodiesel production. RCS Advances 2:11267-11272.

Becker EV (2007) Micro-algae as a source of protein. Biotechnol Adv 25(2):207-210.

Bilad MR, Arafat HA, Vankelecom IFJ (2014) Membrane technology in microalgae cultivation and harvesting: A review. Biotechnol Adv 32:1283-1300.

Bligh EG, Dyer WJ (1959) A rapid method of total lipid extraction and purification. Can J Biochem Physiol 37:911-917.

Chaiklahan R, Nattayaporn C, Wipawan S, Kalyanee P, Boosya B (2010) Cultivation of Spirulina platensis using pig wastewater in a semi-continuous process. J Microbiol Biotechnol 20:609-614.

Cohen Z (1997) The chemicals of Spirulina. In: Vonshak A. (ed) Spirulina platensis (Arthrospira): Physiology, cell biology and biotechnology. Taylor and Francis, London, pp 175-204.

Colla LM, Oliveira RC, Reichert C, Costa JAV (2007) Production of biomass and nutraceutical compounds by Spirulina platensis under different temperature and nitrogen regimes. Bioresour Technol 98:1489-93.

Costa JAV, Colla LM, Filho PD (2003) Spirulina platensis - growth in open raceway ponds using fresh water supplemented with carbon, nitrogen and metal ions. doi: 10.1515/znc-2003-1-214

Dassey AJ, Theegala CS (2013) Harvesting economics and strategies using centrifugation for cost effective separation of microalgae cells for biodiesel applications. Bioresour Technol 128:241-245.

El-Sheekh MM, Farghl AA, Galal HR, Bayoumi HS (2016) Bioremediation of different types of polluted water using microalgae. Rend Fis Acc Lincei 27:401-410.

EPA (2005) Membrane filtration guidance manual. Environ Prot https://www.epa.gov; searched on 23 March 2017 Firestone D.A.O.A.C. (2009) Official Methods and Recommended Practices of the AOCS, 5th ed.; American Oil Chemist's Society: Urbana, IL, USA.

Guillard RRL, Ryther JH (1962) Studies on marine planktonic diatoms I. Cyclotella nana Hustedt and Detonula confervacea (Cleve) Gran Can J Micro 8: 229-239.

Hosikian A, Lim S, Halim R, Danquah M.K. (2010) Chlorophyll extraction from microalgae: A review on the process engineering aspects. Int J Chem Eng doi:10.1155/2010/391632

Hu Q (2013) Environmental effects on cell composition. In Handbook of microalgal culture: Applied phycology biotechnology. Wiley-Blackwell: Hoboken, New York, pp 114-122.

Hultberg M, Lind O, Birgersson G, Asp H (2016) Use of the effluent from biogas production for cultivation of Spirulina. Bioprocess Biosyst Eng doi:10.1007/s00449-016-1726-2

Kim CJ, Jung YH, Oh HM (2007) Factors indicating culture status during cultivation of Spirulina (Arthrospira) platensis. J Microbiol 45(2):122-127.

Klanchui A, Cheevadhanarak S, Prommeenate P (2017) Exploring components of the $\mathrm{CO}_{2}$-concentrating mechanism in alkaliphilic cyanobacteria through genome-based analysis. Computat Struct Biotechnol J 15:340350.

Leema MJT, Kirubagaran R, Vinithkumar NV, Dheenan PS, Karthikayulu S (2010) High value pigment production from Arthrospira (Spirulina) platensis cultured in seawater. Bioresur Technol 101:9221-9227.

Markou G, Georgakakis D (2011) Cultivation of filamentous cyanobacteria (blue-green algae) in agro-industrial wastes and wastewaters: A review. Appl Energ 88:3389-3401.

Markou G, Iconomou D, Muylaert K (2016) Applying raw poultry litter leachate for the cultivation of Arthrospira platensis and Chlorella vulgaris. Algal Res 13:79-84. 
Markou G, Vandamme D, Muylaert K (2014) Ammonia inhibition on Arthrospira platensis in relation to the initial biomass density and pH. Bioresour Technol 166:259-265.

Mata TM, Martins AA, Caetano NS (2010) Microalgae for biodiesel production and other applications: A review. Renew Sust Rev, 14:217-232.

Mezzomo N, Saggiorato AG, Siebert R, Tatsch PO, Lago MC, Hemkemeier M, Costa JAV, Bertolin TE, Colla LM (2010) Cultivation of microalgae Spirulina platensis (Arthrospira platensis) from biological treatment of swine wastewater. Cienc Tecnol Aliment 30(1): 173-178.

Milledge JJ (2011) Commercial application of microalgae other than as biofuels: a brief review. Rev Environ Sci Biotechnol doi:10.1007/s11157-010-9214-7

Muhling M, Belay A, Whitton BA (2005) Variation in fatty acid composition of Arthrospira (Spirulina) strains. J Appl Phycol 17:137-146.

Myers J, Kratz WA (1955) Relations between pigment content and photosynthetic characteristics in a blue-green alga. J gen Physiol 29:11-22.

Ogbonna JC, Yoshizawa H, Tanaka H (2000) Treatment of high strength organic wastewater by a mixed culture of photosynthetic microorganisms. J Appl Phycol 12:277-84.

Phang SM, Miah MS, Yeoh BG, Hashim MA (2000) Spirulina cultivation in digested sago starch factory wastewater. J Appl Phycol 12:395-400.

Priyadarshani I, Rath B (2012) Commercial and industrial applications of microalgae - A review. J Algal Biomass Utln 3(4):89-100.

Rossi N, Derouiniot-Chaplain MP, Legentilhomme P, Petit I (2008) Arthrospira platensis harvesting with membranes: Fouling phenomenon with limiting and critical flux. Bioresour Technol 99:6162-6167.

Safafar H (2017) Microalgae biomass as an alternative resource for fishmeal and fish oil in the production of fish feed. PhD thesis. Technical University of Denmark, Denmark 34-93 pp

Safafar H, van Wagenen J, Møller P, Jacobsen C (2015) Carotenoids, phenolic compounds and tocopherols contribute to the antioxidative properties of some microalgae species grown on industrial wastewater. Mar Drugs 13:7339-7356.

Safi C, Charton M, Pignolet O, Silvestre F, Vaca-Garcia C, Pierre-Yves P (2013) Influence of microalgae cell wall characteristics on protein extractability and determination of nitrogen-to-protein conversion factors. J Appl Phycol doi: 10.1007/s10811-012-9886-1

Sassano CEN, Gioielli LA, Ferreira LS, Rodrigues MS, Sato S, Converti A (2010) Evaluation of the composition of continuously cultivated Arthrospira (Spirulina) platensis using ammonium chloride as nitrogen source. Biomass Bioenerg 34:1732-1738.

Soundarapandian P, Vasanthi B (2008). Effects of chemical parameters on Spirulina platensis biomass production: optimized method for phycocyanin extraction. Internat J Zool Res 4(1):1-11.

Wondraczek L, Batentschuk M, Schmidt MA, Borchardt R, Scheiner S, Seemann B, Schweizer P, Brabec CJ (2013) Solar spectral conversion for improving the photosynthetic activity in algae reactors. Nat Commun doi:10.1038/ncomms3047

Xu Y, Milledge JJ, Abubakar A, Swamy RAR, Bailey D, Harvey PJ (2015) Effects of centrifugal stress on cell disruption and glycerol leakage from Dunaliella salina. Microalgae Biotechnol 1:1-8.

Zarrouk C (1966) Contribution a l'étude du cyanophycée. Influence de divers facteurs physiques et chimiques sur la croissance et la photosynthèse de Spirulina maxima. $\mathrm{PhD}$ thesis, Setch et Gardner, Paris 
540 Table 1. Chemical composition of industrial process water

\begin{tabular}{ccc}
\hline Item & Unit & Amount \\
\hline $\mathrm{pH}$ & - & 8.1 \\
Alkalinity & $\mathrm{mmol} \mathrm{L}^{-1}$ & 62.6 \\
Suspended solids & $\mathrm{mg} \mathrm{L}^{-1}$ & 20 \\
Ammonia + ammonium-N & $\mathrm{mg} \mathrm{L}^{-1}$ & 150 \\
Nitrite + nitrate & $\mathrm{mg} \mathrm{L}^{-1}$ & $<0.1$ \\
Total nitrogen & $\mathrm{mg} \mathrm{L}^{-1}$ & 190 \\
Total phosphorous & $\mathrm{mg} \mathrm{L}^{-1}$ & 11 \\
Sulphate & $\mathrm{mg} \mathrm{L}^{-1}$ & 3.6 \\
Total cyanide & $\mu \mathrm{g} \mathrm{L}^{-1}$ & 2.5 \\
EDTA & $\mathrm{mg} \mathrm{L}^{-1}$ & $<0.5$ \\
Sodium $(\mathrm{Na})$ & $\mathrm{mg} \mathrm{L}^{-1}$ & 1500 \\
Cadmium $(\mathrm{Cd})$ & $\mu \mathrm{g} \mathrm{L}^{-1}$ & $<0.05$ \\
Copper $(\mathrm{Cu})$ & $\mu \mathrm{g} \mathrm{L}^{-1}$ & 3.4 \\
Iron (Fe) & $\mathrm{mg} \mathrm{L}^{-1}$ & 0.23 \\
Cobalt $(\mathrm{Co})$ & $\mu \mathrm{g} \mathrm{L}^{-1}$ & $<0.5$
\end{tabular}

542 Table 2. Concentration $(\mathrm{mg} / \mathrm{L})$ of nitrogen $(\mathrm{N})$ and phosphorous $(\mathrm{P})$ of growth mediums

\begin{tabular}{ccc}
\hline Growth media & Total N & Total P \\
\hline $\mathbf{1 0 0 \%}$ ZM & 412 & 114 \\
$\mathbf{7 5 \%} \mathbf{Z M}+\mathbf{2 5 \%}$ ICW & 356 & 91 \\
$\mathbf{5 0 \%} \mathbf{Z M}+\mathbf{5 0 \%}$ ICW & 301 & 62 \\
$\mathbf{2 5 \%} \mathbf{Z M}+\mathbf{7 5 \%}$ ICW & 245 & 37 \\
$\mathbf{1 0 0 \%}$ ICW & 190 & 11 \\
\hline
\end{tabular}




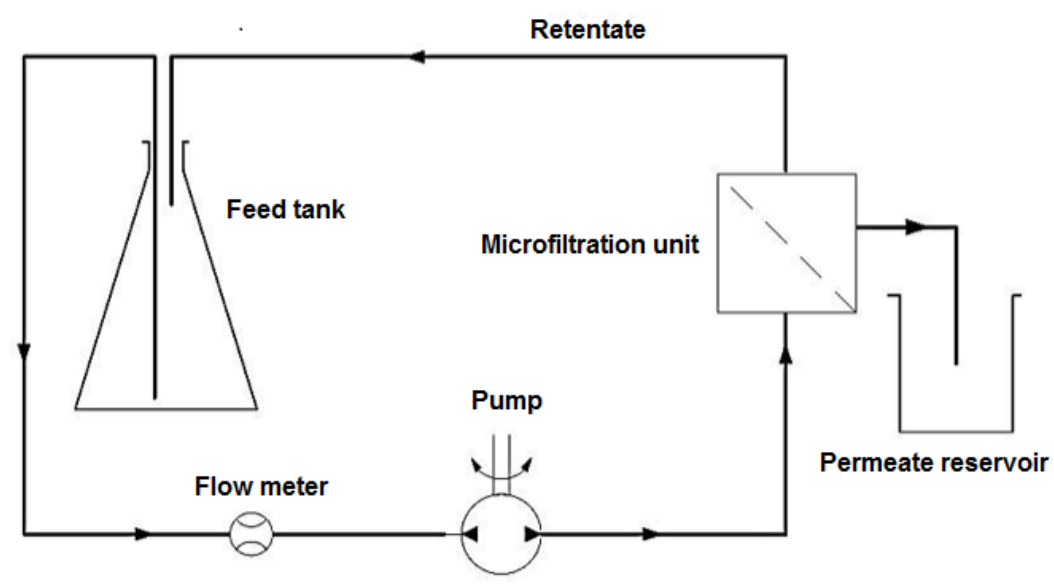

544 Fig. 1 Schematic drawing of the microfiltration process. The pump is forcing the microalgal 545 suspension through the microfiltration unit, where feed is passing across the filter membrane at 546 positive pressure relative to the permeate side. Material, that is smaller in size than the membrane 547 pore size, passes through the membrane as permeate, while the rest is retained on the inner side of 548 the membrane as retentate and subsequently, collected back in the bottle 549

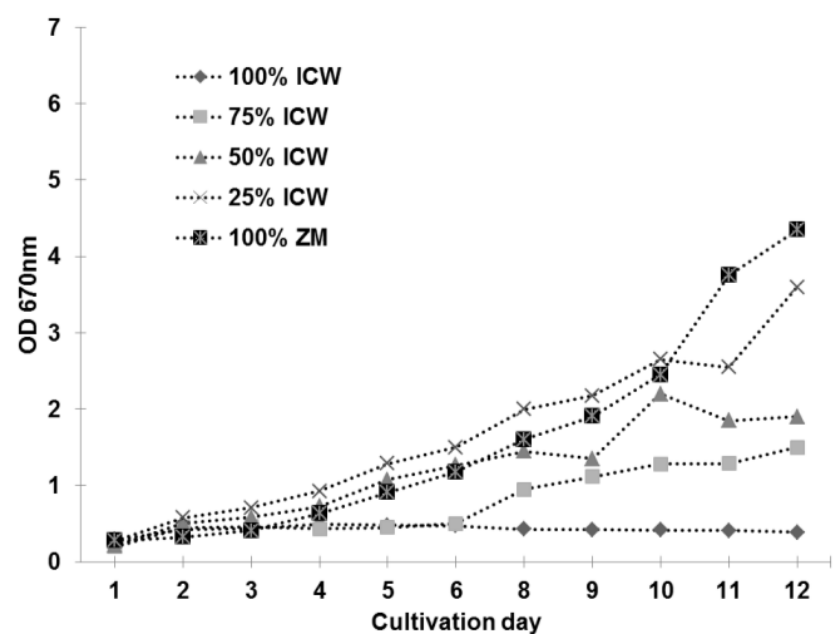

551 Fig. 2 Effect of different concentrations of ICW (25, 50, 75 and 100\%) on growth of A. platensis 552 during 12 days cultivation period $(n=1)$ 


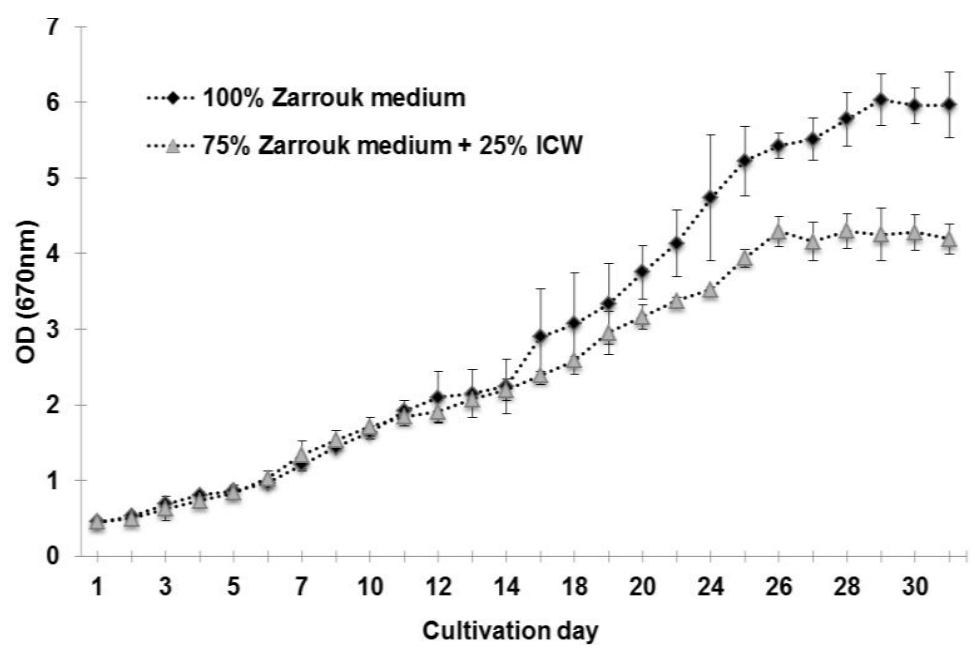

555 Fig. 3 Effect of $25 \%$ ICW on growth of A. platensis during 31 days cultivation period. The results 556 are presented as the means of $\mathrm{n}=4$ measurements from two biological replicates; error bars 557 represent standard deviation

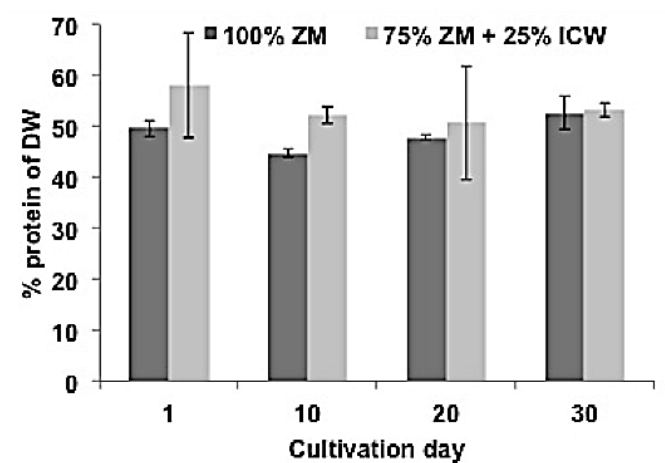

559 Fig. 4 Protein concentration of A. platensis cultivated on 100\% ZM and 25\% ICW over 30 days. 560 The results are presented as the means of $n=4$ measurements from two biological replicates; error 561 bars represent standard deviation.

563 Table 3. Concentration of essential and non-essential amino acids in A. platensis cultivated in $564100 \% \mathrm{ZM}$ and $25 \% \mathrm{ICW}$. The results are presented as the means \pm standard deviation of $\mathrm{n}=4$ 565 measurements from two biological replicates.

\begin{tabular}{ccc}
\hline Experiment & Essential amino acids & Non-essential amino acids \\
\hline $\mathbf{1 0 0 \%} \mathbf{Z M}$ & $56.53 \pm 2.80 \%$ & $43.47 \pm 2.20 \%$ \\
$\mathbf{7 5 \%} \mathbf{Z M}+\mathbf{2 5 \%}$ ICW & $57.83 \pm 0.30 \%$ & $42.17 \pm 0.20 \%$ \\
\hline
\end{tabular}




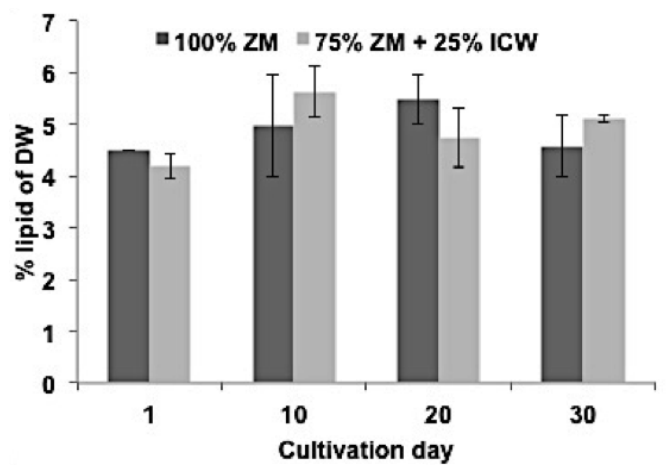

568 Fig. 5 Lipid concentration of A. platensis cultivated on 100\% ZM and 25\% ICW over 30 days. The 569 results are presented as the means of $n=4$ measurements from two biological replicates; error bars 570 represent standard deviation

571

572 Table 4. Fatty acid composition of A. platensis at day 1, 10, 20 and 30 of the 30 day cultivation: (a) 573 in $100 \% \mathrm{ZM}$; (b) in $25 \%$ ICW. Concentrations are expressed as \% of total fatty acid. The results 574 are presented as the means of $n=4$ measurements from two biological replicates. Different letters 575 in the same row represent significant differences $(p<0.05)$

(a)

\begin{tabular}{|c|c|c|c|c|c|c|c|c|c|c|c|c|}
\hline \multirow{2}{*}{$\frac{\text { Fatty acid }}{14: 0}$} & \multicolumn{3}{|c|}{ Day 1} & \multicolumn{3}{|c|}{ Day 10} & \multicolumn{3}{|c|}{ Day 20} & \multicolumn{3}{|c|}{ Day 30} \\
\hline & 2.28 & \pm & 0.12 & 2.16 & \pm & 0.16 & 2.17 & \pm & 0.10 & 1.77 & \pm & 0.22 \\
\hline $14: 1$ & 0.72 & \pm & 0.00 & 1.68 & \pm & 0.29 & 1.41 & \pm & 0.28 & 1.32 & \pm & 0.87 \\
\hline $16: 0$ & 37.97 & \pm & $1.95^{\mathrm{a}}$ & 40.31 & \pm & $1.62^{\mathrm{a}}$ & 40.96 & \pm & $0.70^{\mathrm{a}}$ & 40.55 & \pm & $1.30^{\mathrm{a}}$ \\
\hline $16: 1(n-7)$ & 5.43 & \pm & $0.86^{\mathrm{a}}$ & 3.43 & \pm & $0.18^{\mathrm{b}}$ & 3.13 & \pm & $0.16^{\mathrm{b}}$ & 3.62 & \pm & $0.07^{\mathrm{b}}$ \\
\hline $16: 2(n-4)$ & 0.37 & \pm & 0.09 & 0.20 & \pm & 0.02 & 0.22 & \pm & 0.03 & 0.16 & \pm & 0.02 \\
\hline $16: 3(n-4)$ & 0.18 & \pm & 0.05 & 0.17 & \pm & 0.01 & 0.17 & \pm & 0.01 & 0.12 & \pm & 0.01 \\
\hline 17:0 & 0.10 & \pm & 0.15 & 0.22 & \pm & 0.01 & 0.30 & \pm & 0.00 & 0.33 & \pm & 0.02 \\
\hline $16: 4(n-1)$ & 0.06 & \pm & 0.09 & 0.16 & \pm & 0.02 & 0.18 & \pm & 0.00 & 0.18 & \pm & 0.02 \\
\hline 18.0 & 1.57 & \pm & 0.07 & 1.65 & \pm & 0.04 & 1.37 & \pm & 0.11 & 1.06 & \pm & 0.10 \\
\hline $18: 1(n-9)$ & 3.21 & \pm & $0.35^{\mathrm{a}}$ & 4.79 & \pm & $0.06^{\mathrm{b}}$ & 5.20 & \pm & $0.33^{\mathrm{b}}$ & 5.92 & \pm & $1.42^{\mathrm{b}}$ \\
\hline $18: 1(n-7)$ & 2.47 & \pm & $0.17^{\mathrm{a}}$ & 2.69 & \pm & $0.47^{\mathrm{a}}$ & 1.93 & \pm & $0.14^{\mathrm{a}}$ & 2.61 & \pm & $0.65^{\mathrm{a}}$ \\
\hline $18: 2(n-6)$ & 20.94 & \pm & $0.93^{\mathrm{a}}$ & 23.39 & \pm & $0.11^{\mathrm{b}}$ & 27.19 & \pm & $0.86^{\mathrm{c}}$ & 28.16 & \pm & $0.47^{\mathrm{c}}$ \\
\hline $18: 3(n-6)$ & 21.50 & \pm & $1.65^{\mathrm{a}}$ & 17.23 & \pm & $0.08^{\mathrm{b}}$ & 14.03 & \pm & $0.40^{\mathrm{c}}$ & 12.58 & \pm & $0.77^{\mathrm{c}}$ \\
\hline $18: 3(n-3)$ & 0.05 & \pm & 0.08 & 0.04 & \pm & 0.06 & 0.07 & \pm & 0.02 & 0.08 & \pm & 0.01 \\
\hline $18: 4(n-3)$ & 0.08 & \pm & 0.11 & 0.03 & \pm & 0.05 & 0.05 & \pm & 0.01 & 0.07 & \pm & 0.00 \\
\hline $20: 1(n-11)+(n-9)$ & 0.57 & \pm & 0.52 & 0.08 & \pm & 0.12 & 0.08 & \pm & 0.05 & 0.02 & \pm & 0.01 \\
\hline $20: 2(n-6)$ & 0.17 & \pm & 0.00 & 0.31 & \pm & 0.01 & 0.38 & \pm & 0.02 & 0.41 & \pm & 0.04 \\
\hline $20: 3(n-6)$ & 0.29 & \pm & 0.03 & 0.40 & \pm & 0.05 & 0.53 & \pm & 0.04 & 0.57 & \pm & 0.27 \\
\hline $20: 5(n-3)$ & 0.48 & \pm & 0.11 & 0.22 & \pm & 0.19 & 0.13 & \pm & 0.12 & 0.14 & \pm & 0.00 \\
\hline $22: 1(n-11)$ & 0.37 & \pm & 0.29 & 0.21 & \pm & 0.14 & 0.08 & \pm & 0.11 & 0.00 & \pm & 0.00 \\
\hline
\end{tabular}




\begin{tabular}{|c|c|c|c|c|c|c|c|c|c|c|c|c|}
\hline $22: 5(n-3)$ & 0.51 & \pm & 0.09 & 0.36 & \pm & 0.03 & 0.35 & \pm & 0.08 & 0.14 & \pm & 0.04 \\
\hline $22: 6(n-3)$ & 0.40 & \pm & 0.56 & 0.09 & \pm & 0.06 & 0.04 & \pm & 0.06 & 0.13 & \pm & 0.00 \\
\hline$\Sigma$ SAFA & 41.92 & \pm & $2.29^{\mathrm{a}}$ & 44.34 & \pm & $1.84^{\mathrm{a}}$ & 44.79 & \pm & $0.91^{\mathrm{a}}$ & 43.71 & \pm & $1.26^{\mathrm{a}}$ \\
\hline$\Sigma$ UFA & 57.97 & \pm & $5.98^{\mathrm{a}}$ & 55.49 & \pm & $1.93^{\mathrm{a}}$ & 55.16 & \pm & $2.73^{\mathrm{a}}$ & 56.22 & \pm & $3.18^{\mathrm{a}}$ \\
\hline$\Sigma$ PUFA & 45.03 & \pm & $3.78^{\mathrm{a}}$ & 42.61 & \pm & $0.67^{\mathrm{a}}$ & 43.34 & \pm & $1.65^{\mathrm{a}}$ & 42.74 & \pm & $1.77^{\mathrm{a}}$ \\
\hline
\end{tabular}

(b)

\begin{tabular}{|c|c|c|c|c|c|c|c|c|c|c|c|c|}
\hline \multirow{2}{*}{$\frac{\text { Fatty acid }}{14: 0}$} & \multicolumn{3}{|c|}{ Day 1} & \multicolumn{3}{|c|}{ Day 10} & \multicolumn{3}{|c|}{ Day 20} & \multicolumn{3}{|c|}{ Day 30} \\
\hline & 1.89 & \pm & 0.08 & 2.15 & \pm & 0.16 & 1.29 & \pm & 0.70 & 1.42 & \pm & 0.75 \\
\hline $14: 1$ & 0.44 & \pm & 0.02 & 1.57 & \pm & 0.28 & 1.95 & \pm & 0.51 & 2.72 & \pm & 0.87 \\
\hline $16: 0$ & 38.02 & \pm & $1.49^{\mathrm{a}}$ & 38.23 & \pm & $0.14^{\mathrm{a}}$ & 38.30 & \pm & $1.28^{\mathrm{a}}$ & 37.12 & \pm & $1.30^{\mathrm{a}}$ \\
\hline $16: 1(n-7)$ & 6.55 & \pm & $0.82^{\mathrm{a}}$ & 4.85 & \pm & $0.44^{\mathrm{b}}$ & 4.15 & \pm & $0.11^{\mathrm{b}}$ & 4.25 & \pm & $0.07^{\mathrm{b}}$ \\
\hline $16: 2(n-4)$ & 0.31 & \pm & 0.03 & 0.31 & \pm & 0.06 & 0.26 & \pm & 0.01 & 0.24 & \pm & 0.02 \\
\hline $16: 3(n-4)$ & 0.12 & \pm & 0.00 & 0.17 & \pm & 0.01 & 0.16 & \pm & 0.00 & 0.15 & \pm & 0.01 \\
\hline $17: 0$ & 0.00 & \pm & 0.00 & 0.24 & \pm & 0.00 & 0.25 & \pm & 0.03 & 0.28 & \pm & 0.02 \\
\hline $16: 4(n-1)$ & 0.22 & \pm & 0.03 & 0.21 & \pm & 0.03 & 0.21 & \pm & 0.03 & 0.22 & \pm & 0.02 \\
\hline 18.0 & 1.09 & \pm & 0.01 & 1.38 & \pm & 0.02 & 1.46 & \pm & 0.19 & 1.42 & \pm & 0.10 \\
\hline $18: 1(n-9)$ & 3.23 & \pm & $0.41^{\mathrm{a}}$ & 3.28 & \pm & $0.47^{\mathrm{a}}$ & 4.44 & \pm & $1.05^{\mathrm{a}}$ & 4.52 & \pm & $1.42^{\mathrm{a}}$ \\
\hline $18: 1(n-7)$ & 5.51 & \pm & $0.39^{\mathrm{a}}$ & 5.14 & \pm & $3.24^{\mathrm{a}}$ & 3.95 & \pm & $1.42^{\mathrm{a}}$ & 4.64 & \pm & $0.65^{\mathrm{a}}$ \\
\hline $18: 2(n-6)$ & 22.04 & \pm & $2.44^{\mathrm{a}}$ & 22.14 & \pm & $0.13^{\mathrm{a}}$ & 25.38 & \pm & $0.04^{\mathrm{b}}$ & 26.21 & \pm & $0.47^{b}$ \\
\hline $18: 3(n-6)$ & 18.98 & \pm & $2.28^{\mathrm{a}}$ & 18.59 & \pm & $1.87^{\mathrm{a}}$ & 16.24 & \pm & $0.22^{\mathrm{a}}$ & 14.78 & \pm & $0.77^{b}$ \\
\hline $18: 3(n-3)$ & 0.19 & \pm & 0.18 & 0.02 & \pm & 0.03 & 0.10 & \pm & 0.03 & 0.08 & \pm & 0.01 \\
\hline $18: 4(n-3)$ & 0.06 & \pm & 0.02 & 0.02 & \pm & 0.03 & 0.07 & \pm & 0.00 & 0.09 & \pm & 0.00 \\
\hline $20: 1(n-11)+(n-9)$ & 0.11 & \pm & 0.03 & 0.22 & \pm & 0.31 & 0.03 & \pm & 0.04 & 0.05 & \pm & 0.01 \\
\hline $20: 2(n-6)$ & 0.12 & \pm & 0.00 & 0.25 & \pm & 0.04 & 0.39 & \pm & 0.07 & 0.41 & \pm & 0.04 \\
\hline $20: 3(n-6)$ & 0.14 & \pm & 0.02 & 0.28 & \pm & 0.13 & 0.72 & \pm & 0.37 & 0.73 & \pm & 0.27 \\
\hline $20: 5(n-3)$ & 0.29 & \pm & 0.07 & 0.26 & \pm & 0.08 & 0.25 & \pm & 0.02 & 0.23 & \pm & 0.00 \\
\hline $22: 1(n-11)$ & 0.08 & \pm & 0.00 & 0.02 & \pm & 0.03 & 0.00 & \pm & 0.00 & 0.00 & \pm & 0.00 \\
\hline $22: 5(n-3)$ & 0.31 & \pm & 0.06 & 0.23 & \pm & 0.12 & 0.34 & \pm & 0.01 & 0.34 & \pm & 0.04 \\
\hline $22: 6(n-3)$ & 0.08 & \pm & 0.01 & 0.07 & \pm & 0.02 & 0.00 & \pm & 0.00 & 0.00 & \pm & 0.00 \\
\hline$\Sigma$ SAFA & 41.00 & \pm & $1.58^{\mathrm{a}}$ & 41.99 & \pm & $0.34^{\mathrm{a}}$ & 41.30 & \pm & $2.19^{\mathrm{a}}$ & 40.24 & \pm & $2.16^{\mathrm{a}}$ \\
\hline$\Sigma$ UFA & 58.80 & \pm & $6.79^{\mathrm{a}}$ & 57.62 & \pm & $7.31^{\mathrm{a}}$ & 58.64 & \pm & $3.93^{\mathrm{a}}$ & 59.64 & \pm & $4.68^{\mathrm{a}}$ \\
\hline$\Sigma$ PUFA & 42.87 & \pm & $5.13^{\mathrm{a}}$ & 42.55 & \pm & $2.54^{\mathrm{a}}$ & 44.13 & \pm & $0.80^{\mathrm{a}}$ & 43.47 & \pm & $1.66^{\mathrm{a}}$ \\
\hline
\end{tabular}




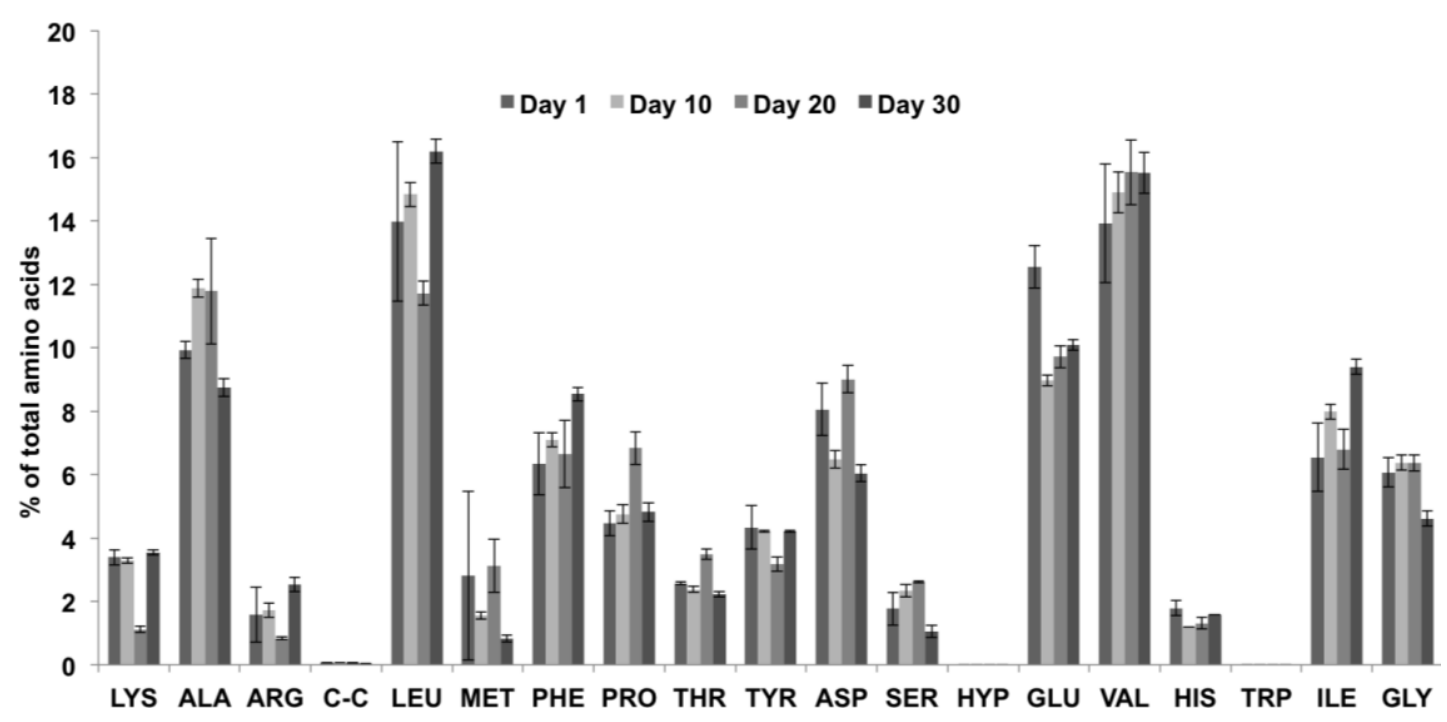

(a)

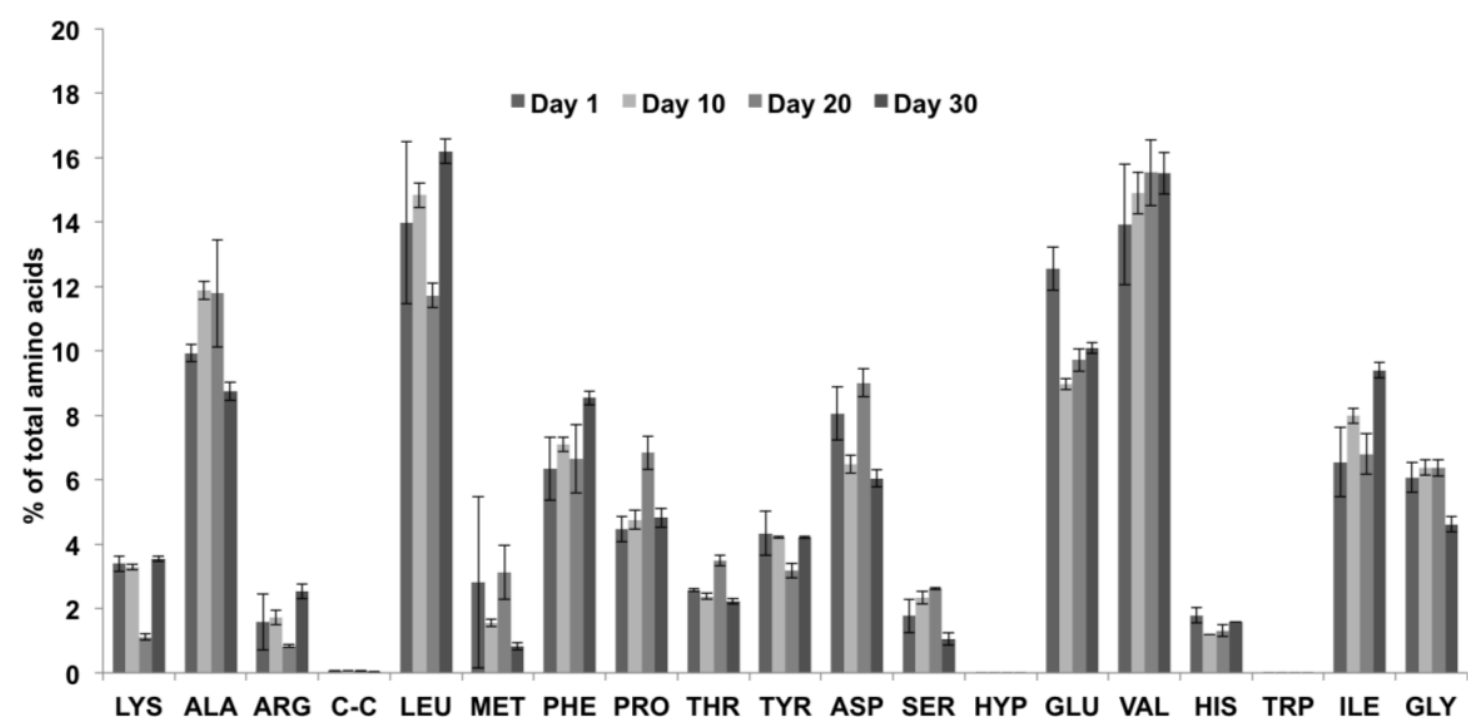

586 Fig. 6 Amino acid composition of A. platensis cultivated in medium containing: (a) 100\% ZM; (b) $58725 \%$ ICW. The results are presented as the means of $n=4$ measurements from two biological 588 replicates; error bars represent standard deviation 


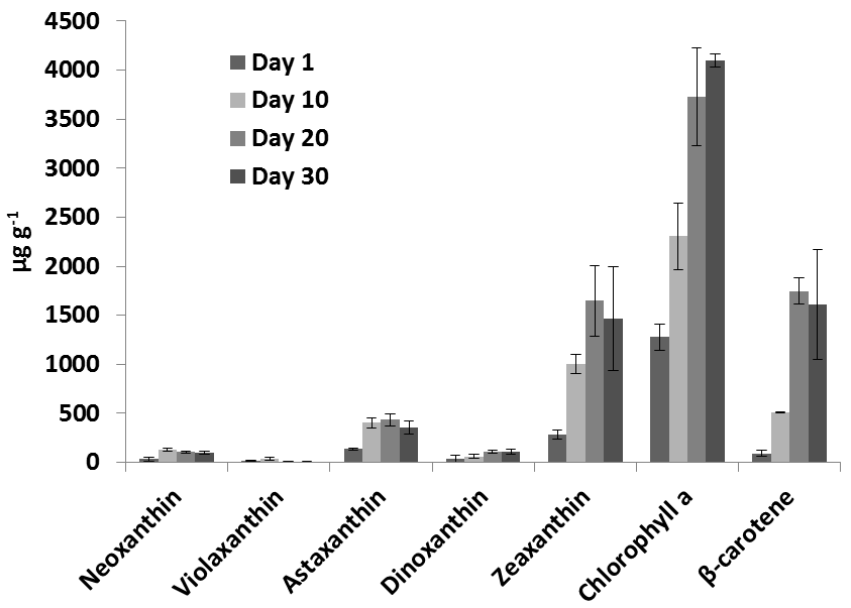

(a)

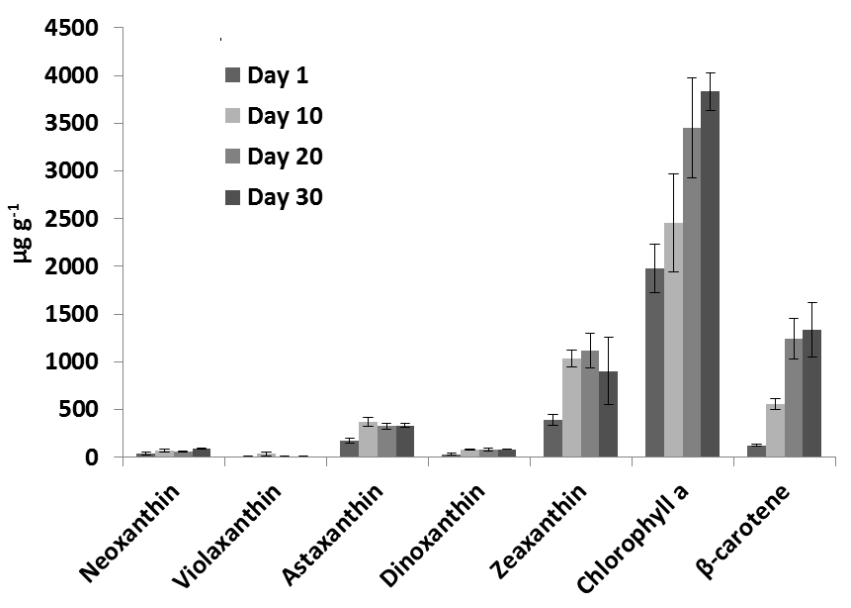

(b)

Fig. 7 Pigment composition and concentration $(\mu \mathrm{g} / \mathrm{g})$ of $A$. platensis cultivated in medium containing: (a) 100\% ZM; (b) 25\% ICW. The results are presented as the means of $\mathrm{n}=4$ measurements from two biological replicates; error bars represent standard deviation

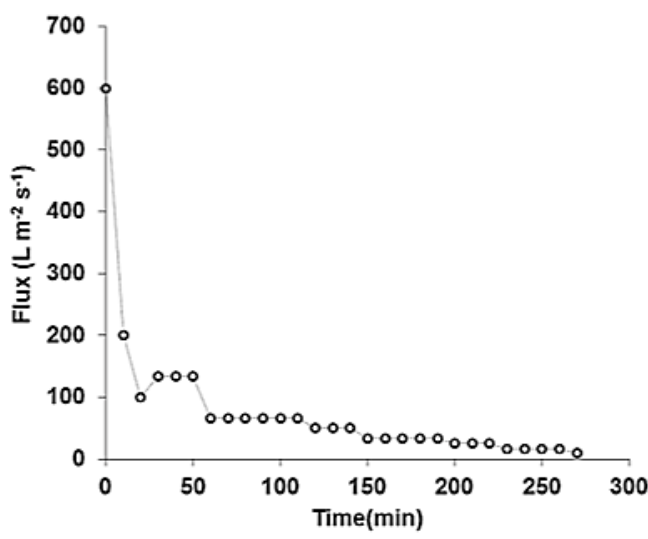

Fig. 8 Harvest performance (flux) for A. platensis harvested by SiC membrane with $3 \mu \mathrm{m}$ pore size 
600

601

602

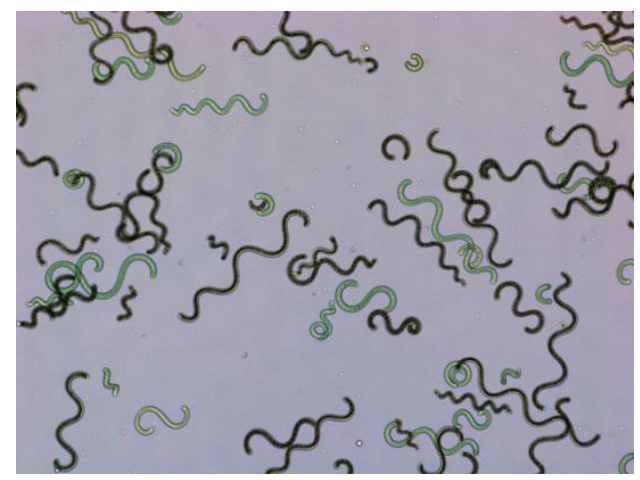

603

(a)

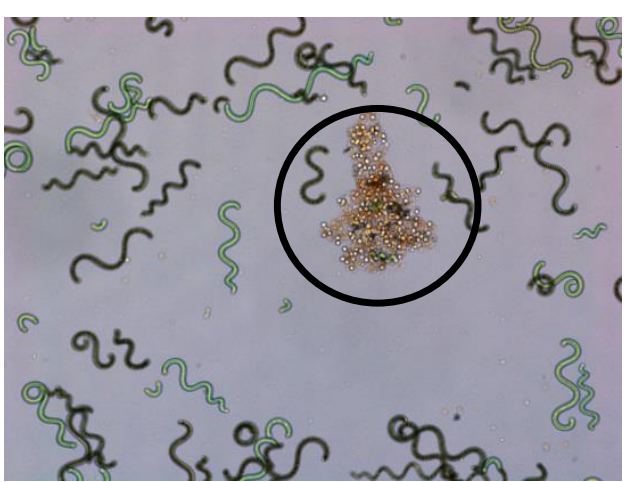

604

(b)

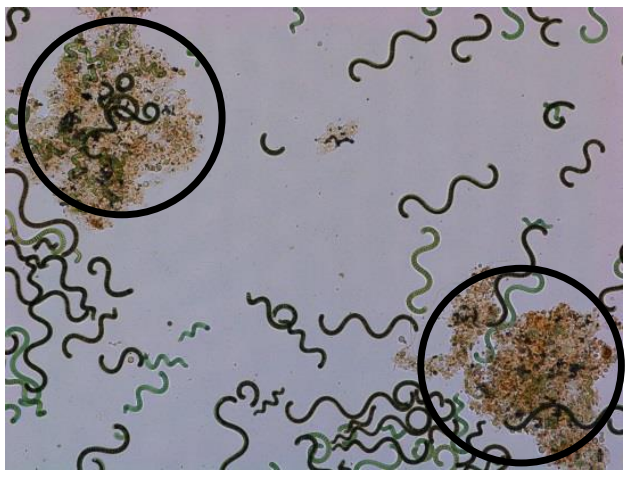

607

(c)

Picture 1. Optical microscopy (100x) of A. platensis: (a) Fresh culture with no cell rupture 610 detectable; (b) Culture after microfiltration with moderate cell rupture detectable; (c) Culture after 611 microfiltration followed by centrifugation with severe cell rupture detectable. Circles indicating 
613 Table 5. Changes in biomass composition of $A$. platensis after microfiltration (MF) and 614 centrifugation (CF). Values are expressed as mean \pm standard deviation of $n=4$ measurements from 615 two replicates

\begin{tabular}{ccccc}
\hline & $\begin{array}{c}\text { Protein } \\
(\boldsymbol{\%} \text { of } \mathbf{D W})\end{array}$ & $\begin{array}{c}\text { Lipid } \\
(\boldsymbol{\%} \text { of } \mathbf{D W})\end{array}$ & $\begin{array}{c}\text { Chlorophyll } \\
(\boldsymbol{\mu} \mathbf{g} / \mathbf{g} \mathbf{D W})\end{array}$ & $\begin{array}{c}\text { Carotenoids } \\
(\boldsymbol{\mu} \mathbf{g} / \mathbf{g} \mathbf{D W})\end{array}$ \\
\hline $\mathbf{M F}$ & $56.70 \pm 2.97$ & $6.06 \pm 0.15$ & $3634.60 \pm 189.49$ & $1010.07 \pm 334.79$ \\
$\mathbf{M F}+\mathbf{C F}$ & $43.69 \pm 2.83$ & $4.40 \pm 0.73$ & $2405.61 \pm 823.29$ & $2229.86 \pm 468.34$ \\
\hline
\end{tabular}

616

617 